\begin{tabular}{|l|l|l||}
\hline \multicolumn{2}{|c|}{ PublisherInfo } \\
\hline \hline PublisherName & $:$ & BioMed Central \\
\hline \hline PublisherLocation & $:$ & London \\
\hline \hline PublisherImprintName & $:$ & BioMed Central \\
\hline \hline
\end{tabular}

\title{
Transcription groupies
}

\begin{tabular}{|l|l|l||}
\hline \multicolumn{2}{|c|}{ ArticleInfo } \\
\hline \hline ArticleID & $:$ & 4508 \\
\hline \hline ArticleDOI & $:$ & $10.1186 /$ gb-spotlight-20020619-02 \\
\hline \hline ArticleCitationID & $:$ & spotlight-20020619-02 \\
\hline \hline ArticleSequenceNumber & $:$ & 174 \\
\hline \hline ArticleCategory & $:$ & Research news \\
\hline ArticleFirstPage & $:$ & 1 \\
\hline \hline ArticleLastPage & $:$ & 2 \\
\hline \hline & & RegistrationDate : 2002-6-19 \\
\hline ArticleHistory & $:$ & OnlineDate \\
\hline \hline ArticleCopyright & $:$ & BioMed Central Ltd2002-6-19 \\
\hline \hline ArticleGrants & $:$ & \\
\hline \hline ArticleContext & $:$ & 130593311 \\
\hline \hline
\end{tabular}




\section{David Bruce}

Email: davidb@thescientisteurope.com

The current theory of eukaryotic gene expression suggests that each individual gene is under the control of its own promoter sequence. In the launch issue of Journal of Biology, Paul Spellman and Gerald Rubin at Howard Hughes Medical Institute and Department of Molecular and Cell Biology, University of California, Berkeley, show that the Drosophila genome contains groups of adjacent genes that have similar gene expression profiles, despite being functionally distinct (Journal of Biology 2002, 1:5).

Spellman and Rubin collected gene expression profiles under 88 different experimental conditions from a total of 267 GeneChip Drosophila Genome Arrays, which had been used to examine a number of experimental conditions in adult and embryonic fruit flies. After mapping the profile for each gene to the gene's chromosomal position they observed that about $20 \%$ of the genes occurred in physically adjacent groups that shared strikingly similar expression patterns.

Along the entire genome they identified about 200 of these groups, each containing between 10 and 30 genes. The average group size was $125 \mathrm{kbp}$ ( $\pm 90 \mathrm{kbp}$ ), with a range of 22 to $450 \mathrm{kbp}$. In addition they found that the groups are not related to chromosomal structures such as polytene bands or nuclear scaffolding sites. At present the mechanism underlying this phenomenon remains unclear, but they postulate that it may be related to 'open' domains of chromatin around a key gene, such that neighboring genes are 'carried along for the ride'.

"As further experiments are carried out it may be that our observation of similarly regulated groups will grow to include all genes - that is, the entire euchromatic genome may be structured in such domains," conclude the authors.

\section{References}

1. Spellman, PT and Rubin GM: Evidence for large domains of similarly expressed genes in the Drosophila genome.Journal of Biology 2002, 1:5., [http://jbiol.com/content/1/1/5]

2. Howard Hughes Medical Institute, [http://www.hhmi.org/]

3. Department of Molecular and Cell Biology, [http://mcb.berkeley.edu/]

This PDF file was created after publication. 